\title{
PENGEMBANGAN TEKNOLOGI PELONTAR BOLA TENIS LAPANGAN BERBASIS MICROCONTROLLER
}

\author{
Hazrina Amni, Yati Ruhayati, Kuston Sultoni \\ Program Studi Ilmu Keolahragaan \\ Departemen Pendidikan Kesehatan dan Rekreasi \\ Fakultas Pendidikan Olahraga dan Kesehatan \\ Universitas Pendidikan Indonesia, Jl. Dr. Setiabudhi No. 229 Bandung \\ Email: yienayin04@gmail.com
}

\begin{abstract}
Abstrak
Penelitian ini bertujuan untuk membuat software dan hardware pelontar bola tenis lapangan berbasis microcontroller. Penelitian ini menggunakan pendekatan metode Research and Development $(R \& D)$. Alat yang dibuat menggunakan rangkaian elektronika berbasis microcontroller, alat ini menggunakan aplikasi bluetooth switch 3.0 yang telah diprogram bersama dengan microcontroller. Alat ini menggunakan 4 motor DC, diantaranya 2 motor utama berfungsi sebagai kecepatan dan 2 motor lainnya berfungsi sebagai penggeraknya. Alat ini bekerja secara otomatis ketika pelaksanaan latihan dimulai dengan ditandai klik tombol on maka alat ini akan langsung berfungsi sebagai alat pelontar bola, tanpa harus berkoneksi terlebih dahulu ke bluetooth switch 3.0. Tapi jika tidak berkoneksi maka alat akan berfungsi hanya dengan satu arah lontaran dan satu kecepatan. Maka dari itu dengan adanya bluetooth switch 3.0 yang digunakan pada alat ini, berbagai mode bisa kita pilih sesui dengan kebutuhan penggunanya. Mode yang terdapat pada alat ini yaitu atas, bawah, kiri, kanan, easy, medium, hard, random, on dan off. Setelah diujicobakan bahwa hasil lontaran bola konsisten dan memiliki standar deviasi yang normal, namun dilihat dari data jarak lontaran bola terlihat perbedaan hasil lontaran yang tidak konsisten. Hal ini menunjukan bahwa salah satu faktor yang mempengaruhi jarak itu sendiri yaitu dilihat dari jenis bola dan struktur bola.

Kata kunci: Pelontar Bola Tenis Lapangan, Microcontroller, Bluetooth Switch 3.0, Motor DC, Software, Hardware
\end{abstract}

\section{PENDAHULUAN}

Tenis lapangan merupakan olahraga yang dimainkan menggunakan raket untuk memukul bola melewati net dan memantulkan sampai lawan tidak dapat mengembalikan bola tersebut. Tenis dimainkan pada arena lapangan berbentuk persegi panjang dan dimainkan mulai dari anak-anak hingga lanjut usia. Teknik dasar dalam permainan tenis, salah satunya yaitu adalah teknik pukulan (stroke) atau lebih dikenal dengan nama Ground stroke. Ground stroke diartikan sebagai memukul bola setelah menyentuh lapangan.

Tentunya untuk menganalisisnya perlu menggunakan teknologi alat pelontar bola tenis yang canggih yang tujuannya untuk melatih teknik Ground stroke. Hal ini menjadi salah satu alasan mengapa saat ini dalam memperbaiki teknik ground stroke banyak menggunakan alat teknologi yang canggih.

Selama ini pelatih tenis lapangan hanya mengarahkan bola secara manual kepada atletnya (feeding), sehingga proses latihan 
hanya berfokus pada pemberian bola, bukan pada perbaikan skill. Dengan demikian pelontar bola diyakini dapat mengatasi masalah tersebut. Feeding dengan alat pelontar bola dapat memberikan kesempatan bagi pelatih untuk memberikan feedback terhadap keterampilan atlet dalam memukul bola. Namun, berdasarkan observasi yang dilakukan (Baegel et al.,2014; Forgeas-Cluck and leger, 2012) ada batas-batas menggunakan mesin pelontar bola untuk pelatihan teknik dan kondisi fisik. Menurut (Carboch et at.,2014) latihan menggunakan alat pemain akan sedikit terpengaruh dengan menjadi berlawanan dengan mesin pelontar bola. Dan ada juga menurut (Smekal et al.2000) dan (Baiget et al. 2014), meskipun situasi lawan menciptakan ketidakstabilan dalam permainan yang menggunakan mesin bola (The Playmate TH - Metaltec and the Pop Lob Airmatic 104) selama mereka melakukan uji coba alat pelontar bola tenis lapangan. Ada juga yang sudah menggunakan alat pelontar bola tetapi masih kurang efektif, dan masih dioperasionalkan dengan cara manual. Belum banyak ditemukan yang memodifikasi alat pelontar bola.

Peneliti ingin mengembangkan sebuah model rancangan alat yang memberi kemudahan serta keefisienan para atlet dan pelatih. Alat ini diharapkan supaya pelatih tidak melakukan proses latihan secara manual lagi. Pelatih hanya mendorong bola dan mengarahkan bola kearah yang diinginkan. Dalam penelitian ini, peneliti akan bekerjasama dengan mahasiswa yang ahli dalam bidang mekanika dan elektro untuk menciptakan Teknologi alat pelontar bola tenis lapangan berbasis microcontroller.

\section{METODE}

Metode yang digunakan adalah metode $\mathrm{R} \& \mathrm{D}$ karena hasil akhir penelitian ini akan menghasilkan produk alat pelontar bola tenis lapangan berbasis microcontroller. Penelitian R\&D dalam Sugiyono (2014) terdapat 10 langkah penelitian. Dalam penelitian ini hanya diadopsi 6 langkah pertama, yakni: (1) Potensi dan Masalah; (2) Pengumpulan Informasi; (3) Desain Produk; (4) Validasi Desain; (5) Perbaikan Desain; (6) Uji Coba Produk.

Pertama, potensi dan masalah. Pengembangan teknologi alat pelontar bola tenis lapangan berbasis microcontroller menjadi sebuah potensi untuk dilakukan penelitian dan pengembangan karena prototipe pelontar bola ini memiliki peran yang sangat penting sebagai alat bantu latihan yang dapat membantu memperbaiki teknik dalam proses latihan. Masalah yang diangkat dalam penelitian ini yaitu pada saat latihan tenis lapangan pelatih hanya melatih secara manual sehingga memungkinkan terjadinya human error. Oleh karena itu, penelitian ini perlu dikembangkan sehingga dapat terciptanya alat pelontar bola tenis lapangan berbasis microcontroller yang dibuat secara efisien dan terjangkau secara biaya.

Kedua, Proses pengumpulan informasi dilakukan secara faktual dengan konsultasi kepada beberapa orang yang mempunyai kemampuan di bidang tenis lapangan agar dapat mengatasi masalah dalam proses latihan. Tidak hanya itu pengumpulan informasi juga didapat dari buku teori metode latihan tenis lapangan, artikel bebas dari suatu situs, jurnal, e-book, handbook, buku refrensi mata kuliah tenis, dan tulisan surat kabar baik yang berupa softcopy yang berhubungan dengan program yang akan dikembangkan. Peneliti juga melakukan konsultasi dengan mekanika mesin POLBAN, mahasiswa mesin POLBAN dan mahasiswa teknik elektro UPI tentang pembuatan alat ini untuk melakukan kerjasama dalam membuat produk yang akan dikembangkan.

Ketiga, Desain produk atau model pengembangan yang dihasilkan adalah terciptanya alat pelontar bola tenis lapangan berbasis microcontroller yang bisa membantu pelatih dalam setiap proses latihan. Alat ini akan bekerja secara otomatis sebagai alat bantu latihan ground stroke pada olahraga tenis lapangan. Terdiri dari 4 motor listrik yang telah 
di program dalam microcontroller yang nantinya akan bekerja secara otomatis dan akan terkoneksi dengan aplikasi bluetooth switch 3.0 yang telah di setting di handphone.

Keempat, Validasi desain merupakan proses kegiatan untuk menilai apakah rancangan produk lebih efektif atau tidak, produk dalam hal ini, adalah alat pelontar bola tenis lapangan berbasis microcontroller. Menurut Sudarwan (1998) (dalam Haryati, S, 2011) suatu model dikatakan valid jika hasil model dapat diterima oleh pengguna dan mampu menjelaskan aktualisasi implementasi. Tahapan validasi merupakan tahapan akhir dari penyusunan model, sebelum dilakukan validasi model perlu adanya verifikasi model, menurut Homby (1994) (dalam Haryati, S, 2011) verifikasi
Kelton (1991, hlm. 299) verifikasi adalah mengecek penerjemahan model simulasi konseptual ke dalam program kerja. Validasi dilakukan dengan meminta pakar dalam bidang penelitian ini berbagai pertimbangan untuk menilai rancangan produk tersebut. Analisis beberapa teori pun dilakukan untuk menilai kualitas rancangan alat ini. Materi pada validasi pembuatan alat ini yaitu meminta pendapat pakar olahraga tenis lapangan dan pakar analisis olahraga tentang produk yang dibuat dan kesesuain kegunaan sebagai salah satu penunjang analisis dan evaluasi latihan tenis lapangan. Adapun tim validasi sendiri adalah dosen pembimbing skripsi peneliti sendiri.

Kelima, Setelah desain produk berupa rancangan alat di evaluasi dan dianalisis oleh

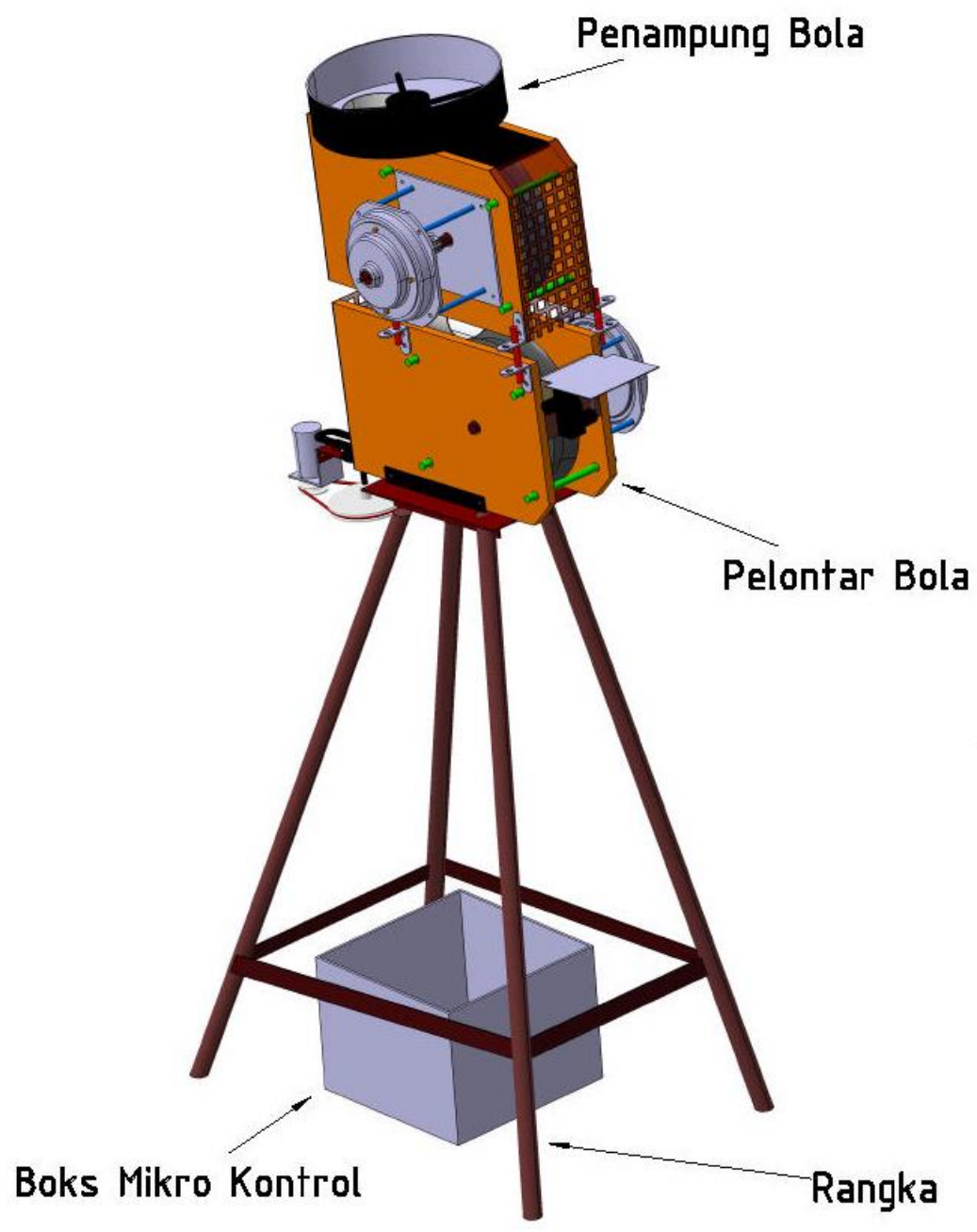

merupakan proses pembuktian bahwa yang para pakar maka akan menghasilkan berbagai diyakini itu benar, sedangkan menurut Law \& masukan dan kelemahan dari rancangan

Gambar 1. Desain Produk alat Pelontar Bola Tenis 
tersebut. Dari hasil inilah kemudian akan dilakukan beberapa perubahan yang menjadikan alat ini menjadi berkualitas. Jika tidak terdapat revisi maka peneliti melanjutkan ke langkah penelitian yang selanjutnya.

Keenam, Setelah perbaikan desain maka dilakukan uji coba produk. Uji coba produk bisa dilakukan beberapa kali sesuai dengan kebutuhan analisis. Pengujian produk ini dilakukan untuk mengetahui karakter, nilai pola, satuan, besaran, serta prinsip kerja teknologi alat pelontar bola tenis lapangan berbasis microcontroller. Kinerja alat pelontar bola tenis lapangan secara nyata diukur berdasarkan kemampuan hasil lontaran bola yang dilakukan.

Alat ini akan bekerja secara otomatis Ketika power dinyalakan, dan aplikasi bluetooth akan menerima sinyal dari microcontroller untuk menggerakan alat serta akan menampilkan menu yang bisa dipilih. Ada beberapa pilihan mode yaitu easy, medium, hard dan random yang terdapat dalam tampilan menu pada aplikasi bluetooth. Setelah dipilih mode dan ditekan ok maka arduino akan mengirimkan perintah ke driver motor dan diteruskan ke motor sesuai dengan mode yang dipilih Untuk mode easy, motor akan bergelak pelan sehingga bola akan keluar dengan lama. Untuk mode medium, motor akan bergerak dengan kecepatan menengah. Untuk mode hard motor akan bergerak dengan kecepatan cepat.

Untuk mode random motor akan bergerak dengan acak, sehingga sulih untuk ditebak. Ketika tombol stop ditekan maka motor akan berhenti dan mulai lagi dari awal.

\section{HASIL DAN PEMBAHASAN}

1. Hasil

a. Profil Produk

Alat ini terdiri dari tiga komponen, (1) komponen rangka (lihat gambar 2); (2) komponen body (lihat gambar 3); dan (3) Remote bluetooth berbasis aplikasi android (lihat gambar 4). Terdiri dari 4 motor listrik yang telah di program dalam microcontroller yang nantinya akan bekerja secara otomatis dan akan terkoneksi dengan aplikasi bluetooth switch 3.0 yang telah di setting di handphone.

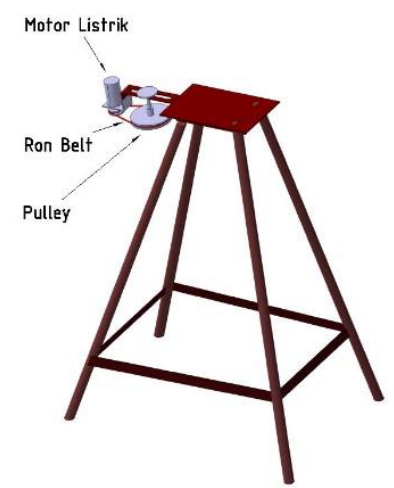

Gambar 2. Komponen Rangka Kaki Alat

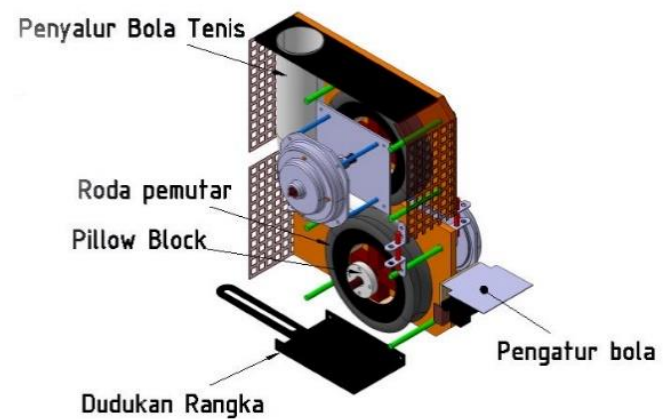

Gambar 3. Komponen body alat

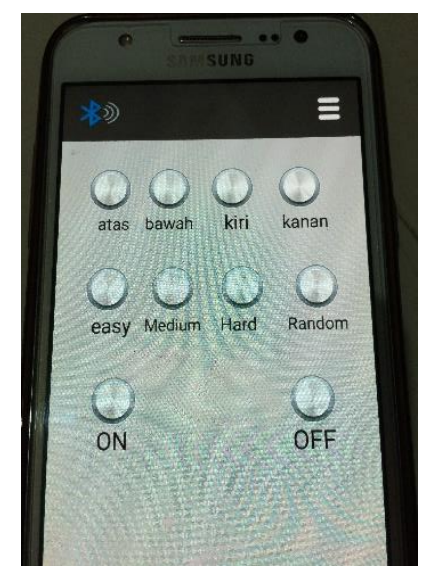

Gambar 4. Tampilan Mode Bluetooth

\section{b. Sistem Kerja}

Alat ini akan bekerja secara otomatis Ketika power dinyalakan, dan aplikasi bluetooth akan 
menerima sinyal dari microcontroller untuk menggerakan alat serta akan menampilkan menu yang bisa dipilih. Ada beberapa pilihan mode yaitu easy, medium, hard dan random yang terdapat dalam tampilan menu pada aplikasi bluetooth. Setelah dipilih mode dan ditekan ok maka arduino akan mengirimkan perintah ke driver motor dan diteruskan ke motor sesuai dengan mode yang dipilih Untuk mode easy, motor akan bergelak pelan sehingga bola akan keluar dengan lama. Untuk mode medium, motor akan bergerak dengan kecepatan menengah. Untuk mode hard motor akan bergerak dengan kecepatan cepat. Untuk mode random motor akan bergerak dengan acak, sehingga sulih untuk ditebak. Ketika tombol stop ditekan maka motor akan berhenti dan mulai lagi dari awal.

\section{c. Uji Coba Produk}

Uji coba produk alat pelontar bola tenis lapangan dilaksanakan di lapangan tennis Indoor UPI dengan melibatkan mahasiswa yang mengikuti UKM tenis lapangan dan temanteman mahasiswa ilmu keolahragaan 2013.

Hasil Analisis Uji Validitas menggunakan teknik korelasi memiliki nilai $\mathrm{p}<0,05$ maka data valid dan nilai $\mathrm{p}>0,05$ maka data tidak valid atau gugur. Nilai signifikansi dari lontaran bola, kecepatan bola dan tinggi antara net ke bola yaitu 0,00 maka data dari uji coba alat dapat dikatakan valid.

Hasil Analisis Uji Reliabilitas memiliki standar nilai alpha $<0,50$ dalam kategori reliabilitasnya rendah. Dalam penelitian ini nilai alpha yang dimiliki yaitu 0,900 termasuk dalam kategori sangat reliabel. Dari hasil penelitian terdapat rata-rata lontaran bola dan standar deviasinya, seperti; rata-rata jarak lontaran 19,50 standar deviasi 2,061, kecepatan lontaran 68,30 standar deviasi 4,302, dan tinggi lontaran dari net 49,23 standar deviasi 4,426. Dari data di atas dapat dikatakan bahwa hasil lontaran bola konsisten dan memiliki standar deviasi yang normal.

Kesimpulan dari hasil uji coba menyebutkan bahwa hasil lontaran bola konsisten dan memiliki standar deviasi yang normal, namun dilihat dari data jarak lontaran bola terlihat perbedaan hasil lontaran yang tidak konsisten. Hal ini menunjukan bahwa salah satu faktor yang mempengaruhi jarak itu sendiri yaitu dilihat dari jenis bola dan struktur bola.

\section{Pembahasan}

Alat pelontar ini berbasis microcontroller yang telah diprogram sesuai dengan kebutuhan analisis peneliti misalnya bola di lontarkan dengan lob ataupun spin yang akan menghasilkan jarak sesuai dengan kebutuhan. Semua mode yang telah di program akan di tampilkan di dalam aplikasi bluetooth. Aplikasi bluetooth ini sendiri tidak bisa terhubung secara otomatis, karena jika terhubung secara otomatis akan mempermudah semua orang menggunakannya. Untuk menggunakannya terlebih dahulu peneliti akan mengatur bluetooth di handpone android yang mau menggunakan alat ini.

Pada penelitian ini peneliti melakukan inovasi pengembangan pada alat sebelumnya diantaranya pertama, membuat dinding alat agar menutupi prototipe sehingga mempercantik alat pelontar dan juga bisa mengantisipasi dari bahaya akibat perputaran roda yang terbuka seperti pada alat yang sebelumnya. Kedua membuat rangka (dudukan alat) agar bisa menunjang kecepatan lontaran bola, karena dilihat dari ukuran lapangan tenis yang jauh dan net yang tinggi maka dibutuhkan daya lecutan yang kuat dan maksimal. Ketiga membuat pengatur bola (lidah bola) yang bisa menciptakan bola spin dan lob, karena pada alat sebelumnya tidak menggunakan lidah bola. Keempat terdapat 2 motor penggerak yang terletak pada lidah bola dan bagian belakang bola yang bisa mengarahkan alat ke kiri dan ke kanan, tidak hanya ke atas dan bawah saja seperti alat sebelumnya.

Alat Pelontar Bola tenis Lapangan berbasis microcontroller memiliki fungsi untuk analisis teknik tenis lapangan diantaranya hasil lontaran bola lob, spin untuk ground stroke dan untuk melatih volley . 


\section{KESIMPULAN}

Alat Pelontar bola tenis lapangan berbasis microcontroller berhasil dirancang dan dikembangkan. Alat pelontar bola dengan tes ground stroke ini dikembangkan oleh peneliti dengan pengembangan pertama, membuat dinding alat agar menutupi prototipe, kedua membuat rangka (dudukan alat) agar bisa menunjang kecepatan lontaran bola, ketiga membuat pengatur bola (lidah bola) yang bisa menciptakan bola spin dan lob, keempat terdapat 2 motor penggerak yang terletak pada lidah bola dan bagian belakang bola.

Komponen utama pada alat pelontar bola tenis lapangan berbasis microcontroller yaitu sebuah microcontroller, arduino uno, motor DC bluetooth switch 3.0 yang dihubungkan ke leptop/handphone. Pada alat ini bluetooth switch 3.0 lah yang berperan untuk menggerakan alat pelontar sesuai dengan keinginan penggunanya. Untuk membuat alat ini membutuhkan waktu selama tujuh bulan, dengan bantuin ahli mekanika dan ahli elektronika.

Hasil uji coba menyebutkan bahwa hasil lontaran bola konsisten dan memiliki standar deviasi yang normal, namun dilihat dari data jarak lontaran bola terlihat perbedaan hasil lontaran yang tidak konsisten. Hal ini menunjukan bahwa salah satu faktor yang mempengaruhi jarak itu sendiri yaitu dilihat dari jenis bola dan struktur bola.

Rekomendasi yang dapat peneliti sarankan yaitu pertama, peneliti perlu melanjutkan penelitian ini untuk Pengembangan alat pelontar bola tenis lapangan berbasis microcontroller ini, peneliti menyadari masih ada kekurangan pada penelitian dan pengembangan alat pelontar ini agar alat yang telah dikembangkan menjadi lebih presisi dalam melakukan fungsinya yaitu sebagai alat pelontar bola tenis lapangan yang pertama, perlu adanya dukungan dari semua pihak khususnya program studi ilmu keolahragaan untuk melanjutkan penelitian dan pengembangan alat ini agar menjadi lebih baik.

Kedua, penggantian motor DC dengan tenaga yang lebih kuat lagi dan tahan lama.

Ketiga, penggabungan tiga element menjadi satu agar alat terlihat simple dan lebih mudah di bawa ke mana-mana.

Keempat, pembuatan software bluetooth sendiri agar bisa terkoneksi tanpa adanya pengaturan.

Kelima, membuat dinding alat yang sebelumnya terbuat dari kayu agar bisa diganti dengan bahan yang lebih bagus lagi.

Keenam, membuat buku paduan tentang alat yang dibuat dan dikembangkan.

Ketujuh, menambah fungsi alat, selain untuk lontaran bola spin alat juga harus dikembangkan lagi untuk bisa menghasilkan lontaran bola slice.

\section{DAFTAR PUSTAKA}

Brown, Jim. (2002). Tenis Tingkat Pemula. Jakarta. PT. Raja Grafindo Persada. Brown, Jim. (2001). Tenis Tingkat Pemula. Jakarta. PT. Raja Grafindo Persada Baiget E., (2014). "On-court endurance and performance testing in competitive male tennis players. Journal of Strength Conditioning and Research"

Carboch J., Suss V., Kocib T. (2014) "Ball machine usage in tennis: movement initiation and swing timing while returning balls from a ball machine and from a real server. Journal of Sports Science and Medicine". Eliezer, Geovanni. (2014). “Electronics Microcontroller, Theory”. [online]. 
http://www.geyosoft.com/2014/merancang-driver-motor-dc

Fargeas-Gluck M.A., Leger L.A. (2012) "Comparison of two aerobic field tests in young tennis players.Journal of Strength Conditioning and Research".

J Sports Sci Med. (2016). Accuracy and Reliability of a New Tennis Ball Machine. [online]. https://www.ncbi.nlm.nih.gov/pmc/articles/PMC4879439/

Purwandono (2012). "Pengaruh Latihan Volley Bola Diumpan Dengan Metode Two Ball Volley Dan Circle Volley Terhadap Kemampuan Pukulan Volley Tenis Pada Petenis Putra Klub Phapros Semarang".

Sugiyono (2011) Metode Penelitian "Researh and Development".

Smekal G., (2000) "Comparison of laboratory and "on-court" endurance testing in tennis. International Journal of Sports Medicine".

Tennis ball machine DIY - part 1. (2013). [online]. Diakses dari :

http://www.google.com

Tennis ball machine DIY - part 2. (2014). [online]. Diakses dari :

http://www.google.com

Yudha, Badruzaman. (2014). Modul Mata Kuliah Pembelajaran Tenis.

Bandung : Universitas Pendidikan Indonesia. 